\title{
Bellwoodilabrus landinii n. gen., n. sp., a new genus and species of labrid fish (Teleostei, Perciformes) from the Eocene of Monte Bolca
}

\author{
Alexandre F. BANNIKOV \\ Borisyak Paleontological Institute, Russian Academy of Sciences, \\ Profsoyuznaya 123, Moscow 117997 (Russia) \\ aban@paleo.ru \\ Giorgio CARNEVALE \\ Dipartimento di Scienze della Terra, Università di Pisa, \\ Via Santa Maria, 53, I-56126 Pisa (Italy) \\ and Museo di Storia Naturale e del Territorio, Università di Pisa, \\ Via Roma, 79, I-56011 Calci (PI) (Italy) \\ carnevale@dst.unipi.it
}

KEY WORDS

Teleostei,

Perciformes,

Labridae,

Bellwoodilabrus landinii,

Eocene,

Monte Bolca, new genus, new species.
Bannikov A. F. \& Carnevale G. 2010. - Bellwoodilabrus landinii n. gen., n. sp., a new genus and species of labrid fish (Teleostei, Perciformes) from the Eocene of Monte Bolca. Geodiversitas 32 (2): 201-220.

\section{ABSTRACT}

A labrid fish, Bellwoodilabrus landinii n. gen., n. sp., is described based on a single specimen collected from the Eocene locality of Monte Bolca, northern Italy. Bellwoodilabrus landinii n. gen., n. sp. is characterized by a prominent frontal relief, broad ethmoid-frontal depression, strongly developed supraoccipital crest, bar-like nasal, jaw teeth arranged in a single row, posterior preopercular margin apparently entire, rounded and molariform lower pharyngeal teeth, six branchiostegal rays, $24(9+15)$ vertebrae, moderately reduced neural spine of the first vertebra, parhypurapophysis absent, XI + 9 dorsal fin elements, III + 9 anal fin elements and 12 pectoral-fin rays. The comparative analysis of morphological and meristic features reveals that Bellwoodilabrus landinii n. gen., n. sp. possesses a combination of plesiomorphic and derived features, which is unique within the Labridae. Bellwoodilabrus landinii n. gen., n. sp. represents the third valid species of the family Labridae described up to now from Monte Bolca. The morphofunctional analysis of the cranial and appendicular skeleton suggests that Bellwoodilabrus landinii n. gen., n. sp. was a benthic invertebrate feeder that inhabited the deep and calm settings along the northern coasts of the central Tethys. The evolutionary significance of the Eocene labrids from Monte Bolca is also discussed. 


\section{MOTS CLÉS \\ Teleostei, \\ Perciformes, \\ Labridae, \\ Bellwoodilabrus landinii, \\ Éocène, \\ Monte Bolca, \\ genre nouveau, espèce nouvelle.}

\section{RÉSUMÉ}

Bellwoodilabrus landinii, nouveaux genre et espèce de Labridae (Teleostei, Perciformes) de l'Éocène du Monte Bolca.

Un poisson labridé, Bellwoodilabrus landinii n. gen., n. sp., est décrit sur la base d'un unique spécimen de l'Éocène du Monte Bolca, Italie du Nord. Bellwoodilabrus landinii $n$. gen., n. sp. est caractérisé par une région frontale proéminente, une large dépression ethmoïdo-frontale, une crête supraoccipitale fortement développée, un os nasal allongé et de forme rectangulaire, des dents orales alignées sur une seule rangée, une marge postérieure du préoperculaire apparemment non dentelée, des dents pharyngiennes inférieures arrondies et molariformes, six rayons branchiostèges, $24(9+15)$ vertèbres, une épine neurale de la première vertèbre relativement réduite par rapport à celles des autres vertèbres, une absence de parhypurapohyse, XI + 9 éléments de la nageoire dorsale, III + 9 éléments de la nageoire anale, et 12 rayons de la nageoire pectorale. L'analyse comparative des caractères morphologiques et méristiques révèle que Bellwoodilabrus landinii n. gen., n. sp. présente une combinaison de caractères plésiomorphes et dérivés, unique chez les Labridae. Bellwoodilabrus landinii n. gen., n. sp. représente la troisième espèce valide de la famille des Labridae du Monte Bolca. Lanalyse morpho-fonctionnelle du crâne et du squelette appendiculaire suggère que Bellwoodilabrus landinii n. gen., n. sp. se nourrissait d'invertébrés benthiques présents dans les environnements calmes et profonds de la côte nord de la Tethys centrale. L'importance des labridés éocènes du Monte Bolca pour la compréhension de l'histoire évolutive de la famille des Labridae est également discutée.

\section{INTRODUCTION}

The Italian Eocene locality of Monte Bolca, located about $25 \mathrm{~km}$ NE of Verona, northern Italy, has been exploited since the 16th century for the extraction of the celebrated beautiful and exquisitely preserved fossil fishes (see e.g., Gaudant 1997). Regular extensive excavations at the Pesciara site started in the mid-19th century, resulting in the extraction of more than 100000 fossils, which are now held in museums, universities and private collections around the world (see Blot 1969). The Monte Bolca fossiliferous limestone date back to the late Ypresian $(-50 \mathrm{Ma})$ and were deposited in a coastal tropical environment characterized by high spatial heterogeneity and structural complexity, close to coral reefs and seagrass beds (Landini \& Sorbini 1996).

The fish fauna includes more that 200 species and is dominated by percomorphs. These taxa include the first representatives of many families living on coral reefs today. However, even though the Monte Bolca fish fauna is broadly similar to the present reef fish assemblages in their familial composition, the numerical abundance of the various families and their taxonomic diversity are remarkably different (Bellwood 1996). For example, labrid fishes, which are extremely diverse and abundant in tropical regions today, are represented by just two valid species at Monte Bolca (see Bellwood 1999).

The family Labridae is a successful diverse group of marine fishes composed of over 600 species (Parenti \& Randall 2000) and characterized by an amazing variety of body shapes, size, colorations and habitats. These fishes inhabit tropical and temperate waters and are most common in shallow biotopes such as coral and rocky reefs, and seagrasses. Feeding habits are also extremely diverse in this group, including bivalves, gastropods, echinoids, crustaceans, fishes, coral mucous, ectoparasites, zooplankton and plants. 
During the field season of 2006 in the Pesciara site, the excavation team of the Museo Civico di Storia Naturale di Verona discovered, among the other fishes, a single specimen of labrid fish. A detailed analysis of the osteology of this fossil indicates unequivocally that it represents a new genus and species of the family Labridae. The purpose of this paper is to describe this new labrid taxon and to discuss its affinities, paleobiology, and evolutionary significance.

\section{METHODS}

The fossil (Fig. 1) was found among the undescribed material resulting from the 2006 excavations at Pesciara site and is deposited in Museo Civico di Storia Naturale di Verona (MCSNV). It is preserved in part and counterpart on laminated micritic limestone. We used a Wild Heerbrugg stereomicroscope rather than a Leica MS5 stereomicroscope equipped with a camera lucida drawing tube. Measurements were taken with a dial calliper, to the nearest $0.1 \mathrm{~mm}$. Comparative data were derived mainly from the literature.

\section{SYSTEMATICS}

\author{
Subdivision TELEOSTEI \\ sensu Patterson \& Rosen, 1977 \\ Order PERCIFORMES \\ sensu Johnson \& Patterson, 1993 \\ Family LABRIDAE Cuvier, 1817
}

Genus Bellwoodilabrus n. gen.

TyPe AND ONLY SPECIES. - Bellwoodilabrus landinii n. sp.

Etymology. - Named in honour of Prof. David R. Bellwood, an Australian ichthyologist and marine biologist (plus the generic name Labrus). His contribution to the systematics, functional morphology, ecology and biogeography of fossil and extant labrid fishes have shed much light on the evolutionary biology of the Labridae.

DiAgNosis. - Body ovoid, with short and deep caudal peduncle; neurocranium with prominent frontal relief; ethmoid-frontal depression present; supraoccipital crest strongly developed, extending anteriorly to the frontals; nasal simple, bar-like; infraorbitals plate-like, with ventral bony fringes; jaw teeth arranged in a single row; enlarged premaxillary canines absent; dentary nearly triangular; posterior preopercular margin entire; lower pharyngeal teeth rounded and molariform; six branchiostegal rays; 24 $(9+15)$ vertebrae; neural spine of the first vertebra moderately reduced; parhypurapophysis absent; dorsal and anal formulae XI + 9 and III + 9, respectively; 12 pectoral-fin rays; first pectoral ray not branched and extremely reduced; scales thin and cycloid, forming scaly sheath at base of anal and spinous dorsal fins; lateral line parallel to dorsal body profile, interrupted below soft dorsal fin.

\section{Bellwoodilabrus landinii n. gen., n. sp.} (Figs 1-4)

HoLOTYPE. - MCSNV IGVR 71214/71215, part and counterpart, complete articulated skeleton, $43.5 \mathrm{~mm}$ total length (TL), $34 \mathrm{~mm}$ standard length (SL). Only known specimen.

ETYMOLOGY. - It is our pleasure to name this species in honour to the Italian paleontologist Prof. Walter Landini, a mentor to one of us (GC), valuable colleague to all of us, in recognition of his contribution to the study of fossil labrids and other Tertiary fishes.

Type LOCAlity AND HORIZON. - Monte Bolca locality, Pesciara cave site; Early Eocene, late Ypresian, middle Cuisian, SBZ 11, Alveolina dainelli Zone (see Papazzoni \& Trevisani 2006).

Diagnosis. - As for the genus.

MeAsurements (as PERCENTAge OF SL). - - Head length $(\mathrm{HL})=31 ;$ maximum body depth $=41$; caudal peduncle depth $=17$; snout length $=10$; orbit diameter $=7.5$; lower jaw length $=16$; distance between tip of the snout and first dorsal-fin spine $=42$; distance between tip of the snout and first dorsal-fin ray $=75$; distance between tip of the snout and anal fin $=66$; distance between pelvic and anal fins $=26$; dorsal-fin base $=53$; spinous dorsal-fin base $=33$; anal-fin base $=30$; length of the first dorsalfin spine $=8$; length of the longest dorsal-fin spine $=13$; length of the first anal-fin spine $=9$; length of the third anal-fin spine $=16$; length of the pelvic-fin spine $=12$; length of the longest caudal-fin ray $\approx 28$.

\section{DESCRIPTION}

The body is moderately elongate, nearly ovoid in outline and laterally compressed, with a short and deep caudal peduncle (Figs $1 ; 2$ ). The head 
is rather large, contained more than three times in SL. The head is relatively deep, its maximum depth almost equals its length; the snout is moderately elongate, contained three times in HL. The mouth is terminal, nearly horizontal, with a moderately large gape. The posterior corner of the lower jaw is situated below the anterior third of the orbit.

The neurocranium is relatively deep and characterized by a developed bony relief (Fig. 3). The vomer is massive and compressed anteroposteriorly. The mesethmoid has a nearly vertical anterior profile. The ethmoid-frontal depression (= frontal recess; see Gomon 1997) is moderately developed. The frontals are characterized by a prominent median bony flange projecting above the orbit. There is a well-developed supraoccipital crest that extends anteriorly to the frontal region. The posterior margin of this crest has a nearly vertical profile. A ridge formed by the epioccipital, parietal and frontal, which terminates along the posterior sector of the frontal region, appears to be present. The parasphenoid is robust, nearly linear, and bears two processes, the adductor process to which the adductor arcuus palatini muscle attaches and a posterior pharyngeal apophysis to which in origin attached an articular process of the third pharyngobranchial; the adductor process (see Rognes 1973; Rosen \& Patterson 1990) is quite elongate, while the pharyngeal apophysis has a rounded ventral profile.

The nasal is a simple bar-like moderately elongate bone that is closely associated to the frontal; this bone is slightly curved and is characterized by a tube for the supraorbital cephalic laterosensory canal oriented through its long axis. What appear to be the third and part of the fourth infraorbital bones can be recognized. These bones are platelike, with a slightly expanded planar bony flange ventrally.

The premaxilla has a well-developed ascending process; as in other labrids, the articular process of the premaxilla appears to be coalescent with the ascending process (Rognes 1973; Rosen \& Patterson 1990). The development of the ascending process of the premaxilla is possibly correlated with the development of the median ethmoid- frontal depression, which partially encloses the distal ends of the ascending processes of the premaxillae, thereby forming the ascending process fossa (see Rognes 1973; Russell 1988; Rosen \& Patterson 1990). The horizontal alveolar process is longer than the ascending process and forms an angle of about $80^{\circ}$ with it. The posterior end of the alveolar process is slightly curved ventrally. The premaxilla bears a single row of progressively smaller conical teeth, which are slightly blunt apically. The maxilla is only partially preserved, represented by the dorsal process (see Van Hasselt 1979), and by part of the anteroventrally curved main axis. The lower jaw is moderately deep, its length slightly exceeds the half of HL. The dentary has a nearly triangular configuration. The symphysis of the dentary is oblique and relatively short. The oral border of the dentary possesses strong and apically blunt conical teeth arranged in a single row. The morphology of the angular and articular is unclear.

The bones of the suspensorium are only partially preserved. The main shaft of the hyomandibula is obliquely oriented. The quadrate is subtriangular in outline. Both the ectopterygoid and endopterygoid are narrow and elongate. The palatine is not preserved.

The opercular bones are not clearly recognizable. The preopercle seems to be slightly curved; there is no evidence of serrations along the posterior margin of this bone.

There are six sabre-like branchiostegal rays, the first of which is narrower and weaker. The large part of the branchial skeleton is badly preserved and the elements are difficult to recognize. The pharyngeal jaws are certainly hypertrophied; a diarthrosis between the upper pharyngeal jaws (third pharyngobranchials) and the pharyngeal apophysis of the parasphenoid was probably present, and the lower pharyngeal jaws (fifth ceratobranchials) are definitely fused. Although the lower pharyngeal jaw probably had some form of physical contact with the cleithrum, there is no evidence of a cleithral articular process fossa, implying that a true synovial joint (Liem \& Greenwood 1981) was probably absent in origin. The pharyngeal teeth are relatively large; those of the lower jaw are rounded 

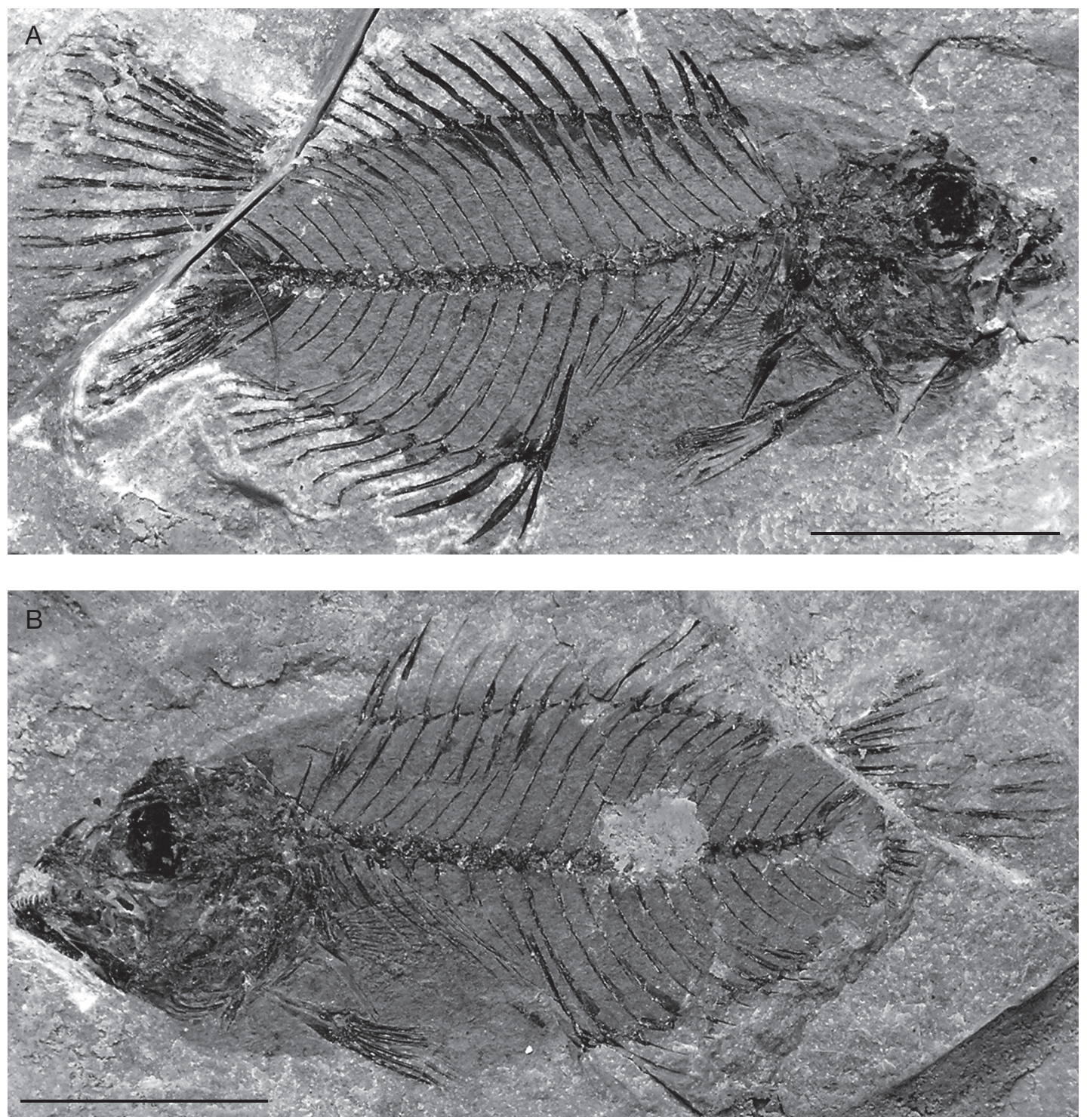

FIG. 1. - Bellwoodilabrus landinii n. gen., n. sp., holotype from the Ypresian of Monte Bolca, Italy: A, MCSNV IGVR 71214, right side, lateral view; B, counterpart, MCSNV IGVR 71215, left side, lateral view. Scale bars: $10 \mathrm{~mm}$.

and molariform, whereas upper pharyngeal teeth mostly have roundly conical crowns.

The vertebral column consists of $24(9+15)$ vertebrae, including the urostyle. The axis of the vertebral column is slightly curved (Fig. 2). The vertebral centra are rectangular to subrectangu- lar, longer than high. The neural spine of the first vertebra is expanded anteroventrally and is slightly shorter than those of the other vertebrae, but not strongly reduced as in many labrid taxa (see Russell 1988; Gomon 1997). Well-developed parapophyses are clearly recognizable in the three 
posterior abdominal vertebrae. Prominent neural prezygapophyses characterize the posterior abdominal vertebrae. The haemal spines of the anterior caudal vertebrae are slightly stronger and longer than the opposite neural spines. There are seven pairs of slender pleural ribs. Thin epineurals articulate on the parapophyses of the seventh and eighth abdominal vertebrae.

The caudal skeleton has the typical labrid structure (Fig. 4). The urostyle is characterized by the fusion of the first preural centrum to the first and second ural centra; it is completely fused to the uroneural, forming a solid block ankylosed to the fused hypurals 3 and 4 . The hypurals 1 and 2 are fused into a roughly triangular hypaxial hypural plate. The reduced fifth hypural ("hypurale minimum"; Monod 1968) is autogenous. There is a deep hypural diastema between the epaxial and hypaxial plates. The parhypural is autogenous; it does not reach the terminal half-centrum and apparently lacks the parhypurapophysis. The haemal spine of the penultimate vertebra is autogenous, while that of the antepenultimate vertebra is fused to the centrum. The neural spine of the penultimate vertebra consists of a short rhomboid crest. There are two epurals, the first of which is longest and more expanded anteroposteriorly. The caudal fin is moderately large and rounded; it consists of 14 principal rays $(\mathrm{I}, 6-6, \mathrm{I})$, plus five upper and four lower procurrent rays.

There is a single thin supraneural, which is nearly straight (Fig. 2). The supraneural is obliquely oriented, extending posteriorly in front of the distal tip of the second neural spine. The dorsal fin is rather elongate, its base extension exceeds half of the body length. The dorsal fin is continuous and originates just above the fifth vertebra. The bases of the two anterior closely associated pterygiophores are located between the neural spines of the second and third vertebrae. The dorsal fin contains nine slender and pungent spines and 11 soft rays, supported by 19 pterygiophores. The spines gradually increase in length from the first to the third, and succeeding spines are almost equally long. The first dorsalfin spine is in supernumerary association on the first dorsal-fin pterygiophore. The pterygiophores of the spiny portion of the dorsal fin are characterized by a narrow and long main shaft that is bordered posteriorly by a medially flattened bony blade; each of these pterygiophores bears a spine in supernumerary association, and the eleventh pterygiophore additionally bears serially associated first soft ray.

The anal fin originates just below the third caudal vertebra and ends at the level of the penultimate vertebra. The anal fin consists of three anal spines and nine branched rays, supported by 10 pterygiophores; the first two anal-fin spines are supernumerary. The spines are strong and show a progressive increase in size. The longest analfin rays are slightly longer than the third anal-fin spine. The first anal-fin pterygiophore is relatively long and sturdy; its shaft is inclined at an angle of about $73^{\circ}$ to the body axis and inserts behind the first haemal spine.

The pectoral girdle is rather robust (Fig. 3). The posttemporal and supracleithrum are poorly preserved. The cleithrum is large and elongate. The ventral postcleithrum is slender and rib-like, whereas the dorsal one is short and wide. The coracoid is relatively narrow, characterized by a long and tapered postcoracoid process. The scapula is difficult to recognize. The radials are incompletely preserved, but all the elements appear to be orientated in the same direction. The base of the pectoral fin is moderately wide and obliquely oriented, located just under the fourth and fifth vertebrae, close to the midpoint between the vertebral column and the ventral profile of the body. The pectoral fin contains 12 relatively short rays. The first ray is very short and not branched.

The basipterygium is a long and narrow bone (Fig. 2). The pelvic fin contains one spine and five rays. The fin inserts at the same level as the pectoral fin insertion. The pelvic-fin rays are longer than the pectoral-fin rays.

Thin cycloid scales cover the entire body, including the bases of the anal and spinous dorsal fin. Some scales reveal few indistinct radii in the basal field. The lateral line has a smoothly curved contour, nearly parallel to the dorsal body profile; it is interrupted under the third soft dorsal-fin ray (Fig. 2). 


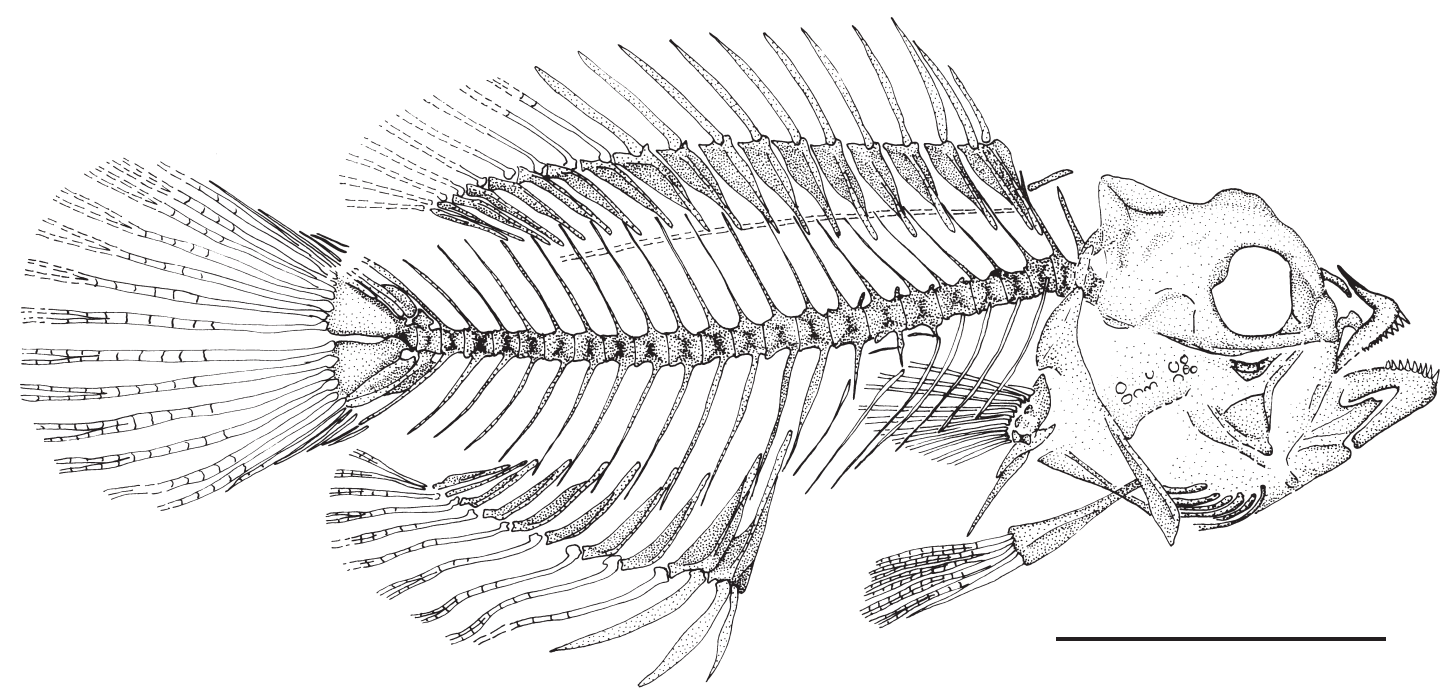

FIG. 2. - Bellwoodilabrus landinii n. gen., n. sp.: reconstruction of the skeleton, right side, lateral view. Scale bar: $10 \mathrm{~mm}$.

\section{DISCUSSION}

THE AFFinITIES OF BELLWOODILABRUS N. GEN. Due to its ecological and structural diversity and disparity, the family Labridae certainly represents one of the most intensively investigated fish group (e.g., Hulsey \& Wainwright 2002; Wainwright et al. 2002, 2004; Westneat et al. 2005; Bellwood et al. 2006; Collar et al. 2008). The morphologi$\mathrm{cal}$ and ecological diversity of these fishes have attracted the attention of biologists operating in many fields (behaviour, biomechanics, ecology, etc.). The taxonomy of labrid fishes has a long and debated history, which dates back to the second half of the 19th century (Günther 1861; Bleeker 1862; Gill 1893; Jordan \& Snyder 1902; Jordan 1923; Norman 1966). In a more recent attempt to recognize the subgroups within this speciose family, Russell (1988) identified not less than six labrid tribes, namely the cheilines, hypsigenyines, labrines, labrichthyines, julidines and novaculines. Moreover, several morphological evidences have supported the inclusion of parrotfishes (scarines) and butterfishes (odacines) as monophyletic assemblages within the Labridae (Liem \& Greenwood 1981; Kaufman \& Liem 1982; Bellwood 1994; Springer \& Johnson 2004). Unfortunately, despite the rapid and continuous progress in the understanding of the ecology and functional anatomy of these fishes, considerable uncertainty remains regarding the definition of the limits of the family Labridae based on morphological features. This is mostly due to the unclear definition of this family within the perciforms since the monophyly and composition of the Labroidei are still debated (Liem \& Greenwood 1981; Kaufman \& Liem 1982; Stiassny \& Jensen 1987; Rosen \& Patterson 1990; Johnson 1993; Streelman \& Karl 1997). For this reason, even though the monophyletic status of the family Labridae is well established and supported by molecular studies (Westneat \& Alfaro 2005), an unequivocal anatomical characterization of this family remains elusive. However, although a comprehensive morphological diagnosis of the family is still lacking, fishes belonging to this family share a certain number of morphological characters that may help to characterize this natural assemblage.

The detailed morphological analysis of the Eocene specimen has revealed several features that strongly support its assignment to the family Labridae, including the general physiognomy of the body, well-developed pharyngeal jaws, development of the adductor process and pharyngeal apophysis on the parasphenoid, nasal closely associated to the frontal, ascending process of the 
premaxilla coalescent with the articular process, a single obliquely oriented supraneural, two epurals, absence of an autogenous uroneural, haemal spine of the antepenultimate vertebra fused to the centrum, epaxial hypural plate fused to the urostyle, reduced fifth hypural, and cycloid scales (Regan 1913; Nelson 1967; Rognes 1973; Yamaoka 1978; Liem \& Greenwood 1981; Kaufman \& Liem 1982; Stiassny \& Jensen 1987; Russell 1988; Rosen \& Patterson 1990; Gomon 1997). Within the Labridae, MCSNV IGVR $71214 / 71215$ possesses a unique combination of features that definitely justify its inclusion in a new, previously unrecognized genus.

As discussed above, the family Labridae includes many tribe-level subgroups (see e.g., Russell 1988). The relationships have been resolved for some of these groups (cheilines, hypsigenyines, labrines, odacines, scarines) using either the morphological (Westneat 1993; Bellwood 1994; Gomon 1997) or molecular (Hanel et al. 2002; Clements et al. 2004) approaches. Recently, a large scale phylogeny for the family Labridae has been proposed by Westneat \& Alfaro (2005). Based on this comprehensive study, the Hypsigenyini Günther, 1861 represents the sister taxon of the remaining labrids, and the odacines must be included within the hypsigenyines. Moreover, cheilines and scarines are sister-groups, closely related to the labrines, and the pseudocheilines, novaculines, and pseudolabrines form successive sister clades to the speciose Julidini Günther, 1861, which represents the crown group of the family Labridae.

The unique combination of features observed in Bellwoodilabrus n. gen. clearly indicates that it cannot be confidently placed within any of the extant labrid tribes. Bellwoodilabrus n. gen. displays a complex mosaic of primitive and derived features, which makes the evaluation of its relationships to the extant labrid tribes rather difficult.

As described above, the body of Bellwoodilabrus n. gen. is moderately elongate and nearly ovoid (Fig. 1). According to Russell (1988), a deep body can be considered as plesiomorphic for the Labridae, thereby implying that the moderately elongate body of Bellwoodilabrus n. gen. should be interpreted as a derived condition.
The neurocranium of Bellwoodilabrus n. gen. apparently has the same complement of bones as the other labrids (see Rognes 1973; Van Hasselt 1979; Russell 1988; Westneat 1993; Bellwood 1994; Gomon 1997). However, some differences exist in its general shape, which varies considerably between members of different tribes (see Gomon 1997). Gomon (1997) pointed out that even if it is rather difficult to ascertain the primitive configuration of the labrid neurocranium, it is likely that the bony relief was reduced and the ethmoid-frontal depression was absent in the ancestral form (see also Russell 1988). Therefore, the neurocranium of Bellwoodilabrus n. gen. appears to be characterized by some derived features, since it has a prominent bony relief (frontal process) in the frontal region and an evident ethmoid-frontal depression (see Fig. 3). Nevertheless, it also possesses a primitive configuration of the supraoccipital crest, which is strongly developed and extends anteriorly to the frontal (see Yamaoka 1978; Russell 1988; Westneat 1993).

The nasal bone of Bellwoodilabrus $\mathrm{n}$. gen. is similar to that of other labrids, and consists of a simple elongate bone closely associated to the neurocranium; a specialized morphology of this bone is characteristic of the pseudocheilines, which possess a posteroventrally directed bony flange on the nasal (see Westneat 1993).

Only the third and fourth infraorbitals are preserved in the single available specimen of Bellwoodilabrus $\mathrm{n}$. gen. As described above, these bones are plate-like, with a ventral bony fringe; such a morphology can be considered as derived, since the primitive condition is represented by simple tubular bones without any kind of ornamentation (Gomon 1997).

The premaxilla of Bellwoodilabrus n. gen. bears progressively smaller conical teeth arranged in a single row, thereby suggesting the presence of a dental ridge; the dentary teeth show a similar configuration. As discussed by Gomon (1997), because of the evolutionary pressures and consequent lability of tooth bearing bones, the ancestral condition of these structures is difficult to define. However, a detailed survey of these structures suggests that the primitive condition for the Labridae could be con- 


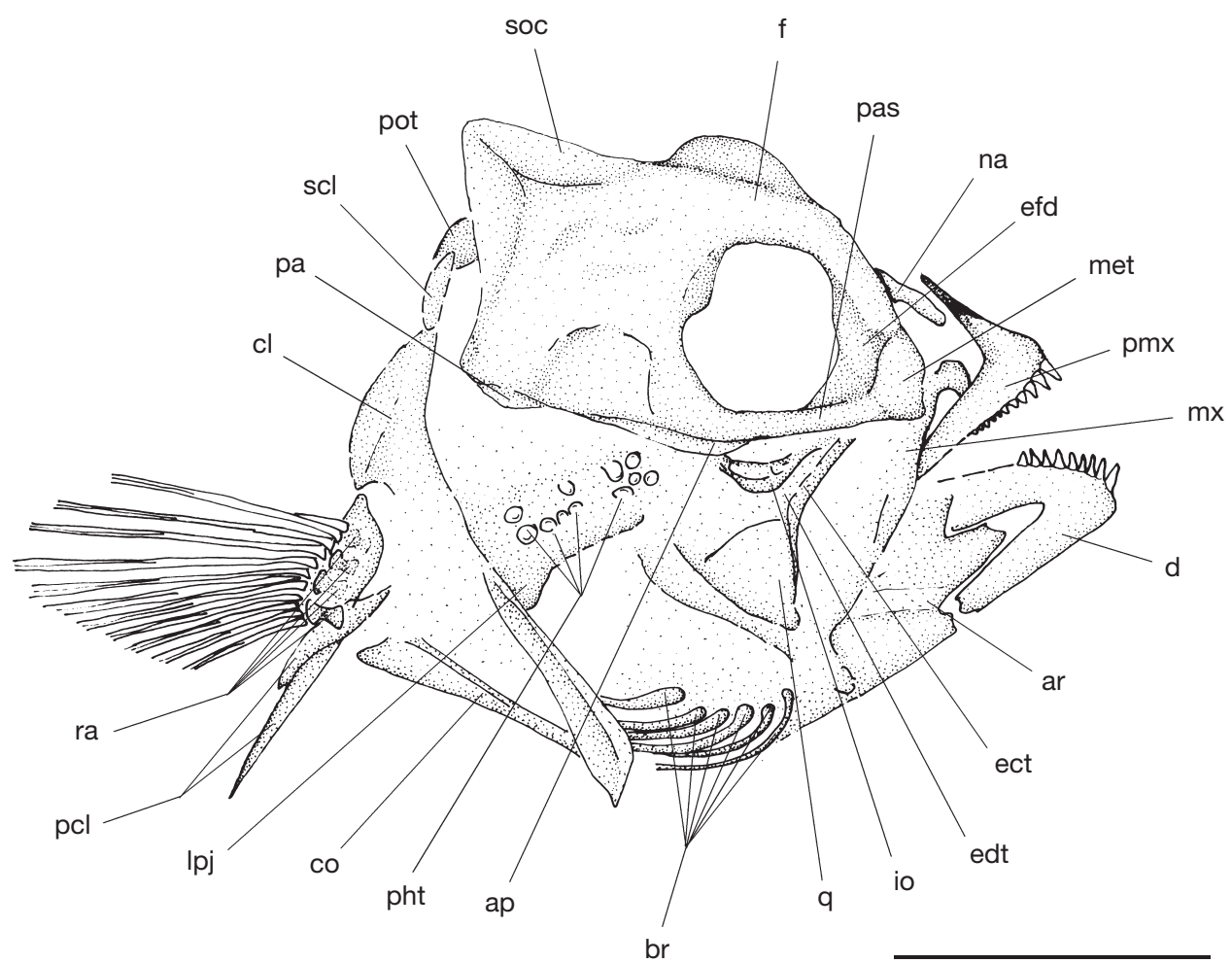

FIG. 3. - Bellwoodilabrus landinii n. gen., n. sp.: reconstruction of the head and pectoral girdle, right side, lateral view. Abbreviations: ap, adductor process; ar, articular; br, branchiostegal rays; cl, cleithrum; co, coracoid; d, dentary; ect, ectopterygoid; edt, endopterygoid; efd, ethmoid-frontal depression; f, frontal; io, infraorbital; Ipj, lower pharyngeal jaw; met, mesethmoid; mx, maxilla; na, nasal; pa, pharyngeal apophysis; pas, parasphenoid; pcl, postcleithrum; pht, pharyngeal teeth; pmx, premaxilla; pot, posttemporal; q, quadrate; ra, radial; scl, supracleithrum; soc, supraoccipital. Scale bar: $5 \mathrm{~mm}$.

sidered as the arrangement of teeth in two distinct rows. Moreover, Gomon (1997) also remarked that the absence of one or few enlarged canines at the posterior end of the premaxilla, as also observed in Bellwoodilabrus n. gen., represents a derived condition. Finally, the nearly triangular shape of the dentary also might be considered to be apomorphic, given that a rectangular configuration of this bone, with a vertical anterior edge and horizontal ventral edge, is considered primitive in general for perciform fishes (Greenwood 1976).

The posterior margin of the preopercle of Bellwoodilabrus $\mathrm{n}$. gen. is entire; such a condition is shared by many labrids, except some labrines and pseudocheilines, and the extinct genus Eocoris, which possess a serrated posterior margin (Rognes
1973; Bannikov \& Sorbini 1990; Westneat 1993). Russell (1988) suggested that the possession of an entire posterior preopercular margin is apomorphic for the Labridae.

Within the labrid fishes, the primitive number of branchiostegal rays is six, while the possession of five branchiostegals represents the derived condition (Russell 1988; Gomon 1997). Bellwoodilabrus n. gen. has six branchiostegal rays. Hypsigenyine labrids usually possess six branchiostegals (Gomon 1997).

The lower pharyngeal jaws of Bellwoodilabrus n. gen. are characterized by large molariform teeth, while the upper pharyngeals bear roundly conical teeth. As far as concerns the pharyngeal dentition, the possession of molariform teeth seems to be a 
TABLE 1. - Meristic values for selected labrid genera. Data from Bannikov \& Sorbini (1990), Bellwood (1990), and Gomon (1997).

\begin{tabular}{|c|c|c|c|c|}
\hline Tribe & Genus & Vertebrae & Dorsal-fin elements & Anal-fin elements \\
\hline Cheilini & $\begin{array}{l}\text { Cheilinus Lacépède, } 1801 \\
\text { Doratonotus Günther, } 1862 \\
\text { Epibulus Cuvier, } 1815 \\
\text { Oxycheilinus Gill, } 1863 \\
\text { Wetmorella Fowler \& Bean, } 1928\end{array}$ & $\begin{array}{l}23 \\
23 \\
23 \\
23 \\
23 \\
\end{array}$ & $\begin{array}{l}19 \\
19 \\
19 \\
19 \\
19 \\
\end{array}$ & $\begin{array}{l}11 \\
12 \\
11 \\
11 \\
11\end{array}$ \\
\hline Hypsigenyini & $\begin{array}{l}\text { Achoerodus Gill, } 1863 \\
\text { Anchichoerops Barnard, } 1927 \\
\text { Bodianus Bloch, } 1790 \\
\text { Choerodon Bleeker, } 1847 \\
\text { Clepticus Cuvier, } 1829 \\
\text { Decodon Günther, } 1861 \\
\text { Lachnolaimus Cuvier, } 1829 \\
\text { Polylepion Gomon, } 1977 \\
\text { Pseudodax Bleeker, } 1861 \\
\text { Semicossyphus Günther, } 1861 \\
\text { Xiphocheilus Bleeker, } 1856 \\
\end{array}$ & $\begin{array}{c}28 \\
27 \\
28 \\
27 \\
28 \\
28 \\
30 \\
28 \\
28 \\
27-29 \\
27 \\
\end{array}$ & $\begin{array}{c}22 \\
22 \\
21-23 \\
20 \\
22 \\
20-21 \\
24 \\
22 \\
23 \\
22 \\
20 \\
\end{array}$ & $\begin{array}{c}14 \\
14 \\
14-16 \\
12-13 \\
15 \\
13 \\
13 \\
14-15 \\
17 \\
15 \\
13 \\
\end{array}$ \\
\hline Julidini & $\begin{array}{l}\text { Coris Lacépède, } 1801 \\
\text { Gomphosus Lacépède, } 1801 \\
\text { Frontilabrus Randall \& Condé, } 1989 \\
\text { Halichoeres Rüppell, } 1835 \\
\text { Hologymnosus Lacépède, } 1801 \\
\text { Leptojulis Bleeker, } 1862 \\
\text { Macropharyngodon Bleeker, } 1862 \\
\text { Oxyjulis Gill, } 1863 \\
\text { Parajulis Bleeker, } 1865 \\
\text { Pseudocoris Bleeker, } 1862 \\
\text { Pseudojuloides Fowler, } 1949 \\
\text { Thalassoma Swainson, } 1839\end{array}$ & $\begin{array}{c}25 \\
25 \\
25 \\
25 \\
25 \\
25 \\
25 \\
26 \\
27 \\
? \\
25 \\
25 \\
\end{array}$ & $\begin{array}{c}21 \\
21 \\
21 \\
20-21 \\
21 \\
20-21 \\
20-21 \\
22 \\
23 \\
21 \\
20-21 \\
21\end{array}$ & $\begin{array}{c}15 \\
14 \\
15 \\
14-15 \\
15 \\
14-15 \\
14-15 \\
16 \\
17 \\
15-16 \\
14-15 \\
14 \\
\end{array}$ \\
\hline Labrichthyini & $\begin{array}{l}\text { Anampses Quoy \& Gaimard, } 1824 \\
\text { Diproctacanthus Bleeker, } 1862 \\
\text { Hemigymnus Günther, } 1861 \\
\text { Labrichthys Bleeker, } 1854 \\
\text { Labroides Bleeker, } 1851 \\
\text { Labropsis Schmidt, } 1931 \\
\text { Larabicus Randall \& Springer, } 1973 \\
\text { Nelabrichthys Russell, } 1983 \\
\text { Neolabrus Steindachner, } 1875 \\
\text { Ophthalmolepis Bleeker, } 1862 \\
\text { Stethojulis Günther, } 1862 \\
\text { Suezichthys Smith, } 1957\end{array}$ & $\begin{array}{l}25 \\
25 \\
25 \\
25 \\
25 \\
25 \\
25 \\
25 \\
37 \\
26 \\
25 \\
25\end{array}$ & $\begin{array}{c}21-22 \\
20 \\
19 \\
20 \\
20 \\
20-21 \\
20 \\
21 \\
31-32 \\
22 \\
20 \\
20\end{array}$ & $\begin{array}{c}15-16 \\
13 \\
13 \\
13 \\
13 \\
13-14 \\
13 \\
15 \\
21 \\
16 \\
14 \\
14\end{array}$ \\
\hline Labrini & $\begin{array}{l}\text { Acantholabrus Valenciennes, } 1839 \\
\text { Centrolabrus Günther, } 1861 \\
\text { Ctenolabrus Valenciennes, } 1839 \\
\text { Labrus Linnaeus, } 1758 \\
\text { Lapanella Jordan, } 1890 \\
\text { Symphodus Rafinesque, } 1810 \\
\text { Tautoga Mitchill, } 1814 \\
\text { Tautogalabrus Günther, } 1862\end{array}$ & $\begin{array}{c}34-37 \\
32-34 \\
32-35 \\
36-39 \\
35 \\
29-34 \\
35 \\
35 \\
\end{array}$ & $\begin{array}{c}26-31 \\
20-29 \\
23-29 \\
28-33 \\
25-29 \\
28-30 \\
27 \\
26 \\
\end{array}$ & $\begin{array}{c}9-14 \\
10-15 \\
9-12 \\
11-16 \\
11-14 \\
11-13 \\
11 \\
11 \\
\end{array}$ \\
\hline Novaculini & $\begin{array}{l}\text { Cymolutes Günther, } 1861 \\
\text { Novaculichthys Bleeker, } 1862 \\
\text { Xyrichthys Cuvier, } 1814\end{array}$ & $\begin{array}{l}26 \\
25 \\
25\end{array}$ & $\begin{array}{c}22 \\
21-23 \\
21\end{array}$ & $\begin{array}{c}14-15 \\
15-17 \\
15\end{array}$ \\
\hline Odacini & $\begin{array}{l}\text { Cheilio Lacépède, } 1802 \\
\text { Haletta Whitley, } 1947 \\
\text { Neoodax Castelnau, } 1875 \\
\text { Odax Valenciennes, } 1840 \\
\text { Siphonognathus Richarson, } 1858\end{array}$ & $\begin{array}{c}25 \\
35-37 \\
38-40 \\
31-46 \\
34-54\end{array}$ & $\begin{array}{c}22 \\
30-31 \\
27-30 \\
23-33 \\
27-47\end{array}$ & $\begin{array}{c}15 \\
15-16 \\
13-15 \\
12-17 \\
11-15\end{array}$ \\
\hline
\end{tabular}


TABLE 1. - Continuation.

\begin{tabular}{llccc}
\hline Tribe & Genus & Vertebrae & Dorsal-fin elements & Anal-fin elements \\
\hline Pseudocheilini & Cirrhilabrus Temminck \& Schlegel, 1845 & 25 & $20-21$ & 12 \\
& Paracheilinus Fourmanoir, 1955 & 25 & 20 & 12 \\
& Pseudocheilinops Schultz, 1960 & 25 & 20 & 12 \\
& Pseudocheilinus Bleeker, 1862 & 25 & 20 & 12 \\
& Pteragogus Peters, 1855 & 25 & 20 & 12 \\
\hline Pseudolabrini & Austrolabrus Steindachner, 1884 & 25 & 20 & 13 \\
& Dotalabrus Whitley, 1930 & 25 & 20 & 13 \\
& Eupetrichthys Ramsay \& Ogilby, 1888 & 25 & 21 & 13 \\
& Notolabrus Russell, 1988 & 25 & 20 & 13 \\
& Pictilabrus Gill, 1891 & 25 & 20 & 13 \\
\hline Scarini & Pseudolabrus Bleeker, 1862 & 25 & 20 & 12 \\
& Bolbometopon Smith, 1956 & 25 & 19 & 12 \\
& Calotomus Gilbert, 1890 & 25 & 19 & 12 \\
& Cetoscarus Smith, 1956 & 25 & 19 & 12 \\
& Cryptotomus Cope, 1871 & 25 & 19 & 12 \\
& Hipposcarus Smith, 1956 & 25 & 19 & 12 \\
& Leptoscarus Swainson, 1839 & 25 & 19 & 12 \\
& Nicholsina Fowler, 1915 & 25 & 19 & 12 \\
\hline Scarus Forssål, 1775 & 25 & 19 & $\mathbf{1 2}$ \\
Unassignated & Bellwoodilabrus n. gen. & 25 & 19 & 11 \\
Monte Bom & Eocoris Bannikov \& Sorbini, 1990 & $\mathbf{2 4}$ & $\mathbf{2 0}$ & 14 \\
\hline
\end{tabular}

derived condition (see Gomon 1997). The structure of the pharyngeal teeth of Bellwoodilabrus $\mathrm{n}$. gen. suggests that the replacement of teeth probably occurred on the posterior margin of the bone, thereby excluding the possibility of phyllodont tooth development (see Bellwood 1990), which has only been observed in certain species of the tribe Hypsigenyini.

The vertebral number is extremely variable within the family Labridae, ranging from 23 to 54 (see Table 1). Bellwoodilabrus $\mathrm{n}$. gen. is characterized by the presence of 24 vertebrae (Fig. 2), representing a unique condition within labrid fishes. The primitive value hypothesized for the vertebral column of the fishes belonging to this family is 28 (Gomon 1997), implying that a decrease in the number of elements could be interpreted as derived.

As documented above, the first vertebra bears a moderately reduced neural spine. The length of the neural spine of the first vertebra varies considerably among labrids (Gomon 1997) and its reduction is considered to be derived (Russell 1988).

The structure and morphology of the haemal spine of the first caudal vertebra is subject to con- siderable variation between different labrid subgroups. For example, hypsigenyines and scarines are characterized by the presence of prominent parapophyseal remnants anterobasally on the first caudal vertebra (Bellwood 1994; Gomon 1997), whereas other lineages lack such parapophyseal (= haemapophyseal of Russell 1988) remnants, or possess a secondary neural arch in order to accommodate the posterior portion of the swimmbladder (see Russell 1988). Russell (1988) hypothesized that the presence of parapophyseal remnants on the first caudal vertebra represents the primitive condition. The haemal spines of the anterior caudal vertebrae of Bellwoodilabrus $\mathrm{n}$. gen. are proximally expanded and these expansions possibly represent parapophyseal remnants. However, the evolutionary significance of this feature is rather difficult to evaluate since the possible presence of secondary haemal arch cannot be detected on the fossil because of inadequate preservation.

Among the Labridae, the caudal skeleton is a relatively conservative structure. The main differences in the morphology of this structure are related to the size of the fifth hypural and the presence of a 
parhypurapophysis. Gomon (1997) suggested that a reduction in size of the fifth hypural represents the derived condition. The fifth hypural of Bellwoodilabrus n. gen. is relatively well developed (Fig. 4), similar to that of hypsigenyines and cheilines (see Fujita 1990). As far as the parhypurapophysis is concerned, the presence of this structure is considered primitive for the Labridae; a parhypurapophysis is absent in Bellwoodilabrus n. gen., being present exclusively in certain hypsigenyines (e.g., Achoerodon Gill, 1864; Bodianus Bloch, 1790; Clepticus Cuvier, 1829; Decodon Günther, 1861; Polylepion Gomon, 1977; Semicossyphus Günther, 1861; Fujita 1990; Gomon 1997).

Meristic features are widely used to evaluate labrid intrarelationships, since they show no or little variation in many subgroups, thus representing useful tools to establish the affinities of labrid genera (see Table 1). Bellwoodilabrus n. gen. has 20 dorsal-fin and 12 anal-fin elements. A similar complement of median fin elements is characteristic of pseudocheilines (see Table 1), which are clearly not related to Bellwoodilabrus n. gen. (cf. Westneat 1993). Gomon (1979) hypothesized that the primitive number of dorsal-fin elements in the Labridae is 22 and the primitive number of anal-fin elements is 18 , thereby implying that the complement of median fin elements of Bellwoodilabrus n. gen. should be considered to be derived.

The number of pectoral-fin rays is highly variable among labrids and counts greater than 14 elements appear to be the primitive condition (Bellwood 1994). Certain members of the basal tribe Hypsigenyini (e.g., Polylepion) possess up to 19 pectoral-fin rays. The pectoral fin of Bellwoodilabrus $\mathrm{n}$. gen. contains 12 rays; such a number of pectoral-fin elements is considered to be derived (see Westneat 1993). A further derived feature of the pectoral fin of Bellwoodilabrus n. gen. is the presence of an extremely shortened, rudimentary first pectoral ray (Russell 1988).

In summary, the analysis of selected morphological and meristic features discussed above reveals that the affinities of Bellwoodilabrus n. gen. are difficult to evaluate. It shows a unique combination of derived (moderately elongated body, presence of an ethmoid-frontal depression, prominent neurocra- nial bony relief, plate-like infraorbital with ventral bony fringes, jaw teeth arranged in a single row, enlarged canines at the posterior end of the premaxilla absent, dentary nearly triangular in shape, posterior preopercular margin entire, pharyngeal teeth molariform, 24 vertebrae, neural spine of the first vertebra reduced, parhypurapophysis absent, 20 dorsal-fin elements, 12 anal-fin elements, 12 pectoral-fin rays, first pectoral ray rudimentary) and plesiomorphic (supraoccipital crest extending anteriorly up to the frontals, nasal simple, six branchiostegal rays, [?] presence of parapophyseal remnants on the first caudal vertebra, relatively welldeveloped fifth hypural) features found in none of the labrid subgroups, suggesting that it cannot be confidently accommodated within any subfamilial category. Thus, following the recommendations of Patterson \& Rosen (1977), since none of the diagnostic features by itself is unique among the labrids, and because its sister-group relationships cannot be demonstrated definitely, Bellwoodilabrus n. gen. is placed herein incertae sedis among the Labridae (see also Bannikov \& Carnevale 2007).

\section{Paleobiology of BELLWOOdILABRUS N. GEN.}

Among fishes, labrids present a unique spectacular ecological diversity, which is primarily associated with their feeding biology, functional morphology of locomotion and reproductive natural history (e.g., Randall 1967; Warner \& Robertson 1978; Wainwright 1988; Westneat 1995; Walker \& Westneat 2002). Such extensive ecological diversity is reflected in biomechanical diversity of the feeding and locomotory mechanisms, and for this reason labrids are currently regarded as a model group for studying the evolution of these mechanisms and the mechanical basis of feeding and locomotory performance. Labrids play a central role in the ecology of tropical marine environments as they occupy virtually all major feeding guilds on reefs (molluscivores, crustacean feeders, piscivores, mucivores, planktivores, detritivores, herbivores, etc.; Randall 1967), being distributed in both the shallow and deeper reef habitat zones (Fulton et al. 2001). The feeding apparatus of these fishes is characterized by an extensive variation in the major feeding muscles and skeletal linkage systems used 
for biting and manipulating prey, suction feeding, and processing in the pharyngeal jaws (Wainwright et al. 2004). Trophic diversity in labrids seems to be strongly reflected by interspecific variation in the feeding-related structures. The skulls of labrids are complex mechanical systems characterized by several movable elements and a diversity of anatomical designs (see Wainwright et al. 2004; Westneat et al. 2005). Some models borrowed from mechanical engineering were developed to investigate the biomechanics of feeding in these fishes as a system of levers and linkages that transmits the forces of contracting muscles to jaws (Van Hasselt 1978; Westneat \& Wainwright 1989; Westneat 1990, 1994). Such biomechanical analyses have revealed that labrid fishes have on several occasions evolved extremely different linkage designs (Westneat et al. 2005). In general, in labrids the skull function shows repeated patterns of evolutionary divergence and convergence, suggesting that they have undergone extensive radiation along axes of cranial biomechanics in response to the opportunities that different preys present in marine habitats (Westneat et al. 2005).

As evidenced in the descriptive section, the feeding related structures of Bellwoodilabrus n. gen. are moderately well preserved but, at the same time, only partially complete; the premaxilla and mandible are clearly recognizable, while the maxilla and suspensorium are largely incomplete (Fig. 3); moreover, the exact structure of the pharyngeal jaws is difficult to interpret even though the morphology of the pharyngeal teeth can be easily observed. The incompleteness of the feeding related structures of Bellwoodilabrus n. gen. makes it extremely difficult to evaluate the kinematic coefficients resulting from the analysis of lever and linkage systems (see Wainwright et al. 2004; Alfaro et al. 2005). Therefore, a complete evaluation of the mechanical properties of the major components of the feeding mechanism of Bellwoodilabrus n. gen. cannot be realized, implying that a detailed functional comparison between Bellwoodilabrus n. gen. and other extant labrid genera remains elusive. Nevertheless, some information about feeding habits and trophodynamics of Bellwoodilabrus n. gen. can be obtained from the functional analysis of its cranial anatomy. The existence of a causal con- nection between morphology and performance or between form and function is strongly intuitive and many authors considered them as closely related concepts or have a mutually predictable relationship (see e.g., Dullemeijer 1974). Inferring the function of structures from anatomical analyses is a common practice in paleontological studies (e.g., Gould 1970; Alexander 1989; Rayner \& Wotton 1991 ), even if the lack of information on motor programs in the central nervous system clearly limits our ability to generate predictions about ecology and behaviour of extinct organisms (see Lauder 1995). Moreover, recent studies revealed that labrids display a weak correlation between the degree of morphological specialization and the extent of dietary specialization (Bellwood et al. 2006). Despite such limitations, several predictions on the general functions or behavioural properties of Bellwoodilabrus n. gen. can be generated based on the considerable body of data assembled up to date on extant labrids.

As many other labrids, Bellwoodilabrus n. gen. probably used a combination of ram, suction and manipulation feeding (Ferry-Graham et al. 2002). Its stout conical raptorial teeth (Fig. 3), that closely resemble those of certain crustacean predators (Wainwright et al. 2004), were probably used in gripping relatively large invertebrate preys. The lower jaw of Bellwoodilabrus n. gen. appears to be only slightly thickened and structurally reinforced and the ethmovomerine block of the neurocranium is straight and horizontal; these features suggest that its skull was not adapted to generate an increased biting force (Otten 1983). Such hypothesis seems to be confirmed by the elongation of the ascending process of the premaxilla, which indicates that Bellwoodilabrus n. gen. was able to produce a large protrusion, resulting in a relatively enlarged buccal cavity. Protrusibility seems to be correlated to the size of the supraoccipital crest as an expression of the epaxial (and thus expansion) musculature (Barel 1983). The supraoccipital and temporal areas of the neurocranium of Bellwoodilabrus n. gen. are relatively well developed (Fig. 3); such a condition appears to be indicative of a moderate to large development of the epaxial muscles. However, the supraoccipital and temporal space is not necessarily used to exclu- 
sively accommodate enlarged epaxial muscles, since in certain labrids these sectors of the neurocranium represent the sites of insertion of the levator posterior and fourth levator externus muscles (see Yamaoka 1978; Kaufman \& Liem 1982; Wainwright 1988). These muscles originate from the neurocranium and insert on the lower pharyngeal jaw, facilitating the forceful occlusion of these jaws and the crushing of hard prey (Yamaoka 1978; Wainwright 1987). The relatively large size and the wide posterior extension of the supraoccipital crest of Bellwoodilabrus $\mathrm{n}$. gen. suggest that this area represented the main site of origin of a large levator posterior muscle, similar to the condition observed in certain species of the genera Bodianus, Cheilinus Lacépède, 1801, Cheilio Lacépède, 1802, Choerodon Bleeker, 1847. Halichoeres Rüppell, 1835 and Macropharyngodon Bleeker, 1862 (Yamaoka 1978; Wainwright et al. 2004), which feed mainly on crustaceans, molluscs and echinoids. Yamaoka (1978) observed that the labrid species which exhibit a well-developed levator posterior possess a developed lower pharyngeal bone with molariform teeth; as described above, Bellwoodilabrus n. gen. apparently possesses a strongly ossified enlarged lower pharyngeal jaw characterized by large, rounded molariform teeth. The pharyngeal jaw crushing strength, which is related to the relative development of the pharyngeal jaws, plays a central role in constraining the diets of labrid fishes (Wainwright 1988), since species with stronger pharyngeal jaws (and muscles) have the potential to eat a greater range of shelled prey types (and thus a greater range of prey types) than weaker jawed congeners.

In a recent paper, Collar et al. (2008) demonstrated that locomotor and feeding morphologies have diversified in concert in labrid fishes, implying a history of integrated locomotor and feeding performance evolution. For example, changes in the skull to increase jaw speed are associated with pectoral fin shape changes that increase swimming performance; moreover, increases in the skull's force output seem to be correlated with changes in the pectoral fin to produce greater thrust at slow speeds. Such correlation may derive from associations between habitat and prey which limit the possibilities for independent skull and fin diversification.
Labrids use the pectoral fins as the primary source of propulsion (labriform locomotion; see Webb 1994). Considerable complexity and diversity in swimming modes have been observed within the Labridae, so that they display the greatest range of swimming modes found in a single teleost family (Bellwood \& Wainwright 2001). Their locomotory diversity varies between the use of a pure flapping (up-down) stroke and the oscillation with a rowing (fore-aft) stroke (Walker \& Westneat 2002). Fin shape is correlated with propulsive mechanism and swimming performance. Fin motion and locomotor strategy are associated to several key parameters of fin shape, including fin aspect-ratio ([length of the

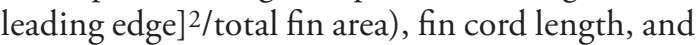
the distribution of fin area (Walker \& Westneat 2000, 2002). Species characterized by a rowing behaviour exhibit rounded and low aspect-ratio pectoral fins with a short leading edge, while flapping species display more elongate, high aspectratio with a long leading edge (Walker $\&$ Westneat 2000; Fulton et al. 2001). Taxa that displayed high aspect-ratio pectoral fins are able to sustain faster swimming speeds, while those characterized by low fin aspect-ratio are slower swimmers specialized for maneuvering. Aspect-ratio appears to be strongly correlated with the orientation of the fin where it attached to the body (Wainwright et al. 2002). The angle of attachment of the fin measures the orientation of the joint between fin-ray bases and the radial elements upon which the rays rotate (Westneat 1996; Wainwright et al. 2002). In this context, fins with high aspect-ratio tend to attach at a shallower angle to the main body axis than in species with lower fin aspect-ratio, suggesting a more vertical axis of fin motion. The pectoral fins of Bellwoodilabrus n. gen. are poorly developed (Figs $1 ; 2$ ), with a rounded profile and a relatively short leading edge. The angle of orientation of the base of the pectoral fin on the long axis of the body measures approximately $63.5^{\circ}$. The exact fin aspect-ratio of Bellwoodilabrus n. gen. cannot be confidently calculated because the maximum area of the fin is extremely difficult to estimate. However, the general morphology of the fin and its relative dimensions suggest that the fin aspect-ratio was rather low, which is congruent with a high at- 
tachment angle. The first unbranched pectoral-fin ray of Bellwoodilabrus n. gen. is extremely short, thereby implying that the leading edge of the fin was rather flexible. Moreover, all the pectoral-fin radials are roughly oriented in the same direction, yielding an approximately uniform rotation for all fin rays (see Thorsen \& Westneat 2005). Therefore, the structure and morphology of the pectoral fin clearly indicate that Bellwoodilabrus landinii n. gen., n. sp. was a slow swimming taxon. Studies of habitat use in extant labrids reveal that taxa characterized by low aspect-ratio fins are more abundant in deep and calm habitats, mostly in close association with the structure of the reef (Bellwood \& Wainwright 2001; Fulton et al. 2001). Low aspect-ratio taxa appear to be largely restricted to a position that is close to the substratum being uncommon in shallow settings characterized by high wave exposure. Bellwood \& Wainwright (2001) pointed out that the few low aspect-ratio individuals recorded from exposed locations are closely associated with the substratum, hiding in holes or under corals. As documented above, the angle of attachment of the pectoral fin of Bellwoodilabrus n. gen. measures nearly $63.5^{\circ}$. This value is comparatively very high, given that in a recent survey of labrid pectoral fin features that parameter ranges from about $22^{\circ}$ to about $67^{\circ}$ (Wainwright et al. 2002). In this respect, Bellwoodilabrus n. gen. closely resembles certain cheiline and pseudocheiline genera, such as Cheilinus, Oxycheilinus Gill, 1863, and Pseudocheilinus Bleeker, 1862, which are characterized by the lowest aspect-ratio fins and highest fin attachment angles $\left(60.8-66.3^{\circ}\right)$ observed within the family Labridae. These Indo-Pacific taxa primarily occupy microhabitats close to the reef substrate that are characterized by low level of water motion (Bellwood \& Wainwright 2001; Fulton et al. 2001), where they feed on benthic invertebrates, mostly crustaceans, molluscs, and echinoids. A similar diet seems to be consistent with the cranial attributes of Bellwoodilabrus n. gen.

In summary, the functional analysis of the cranial and appendicular skeletal morphology of Bellwoodilabrus $\mathrm{n}$. gen. seems to indicate that it was a benthic invertebrativore, which was also able to feed on hard-shelled preys; it probably lived close

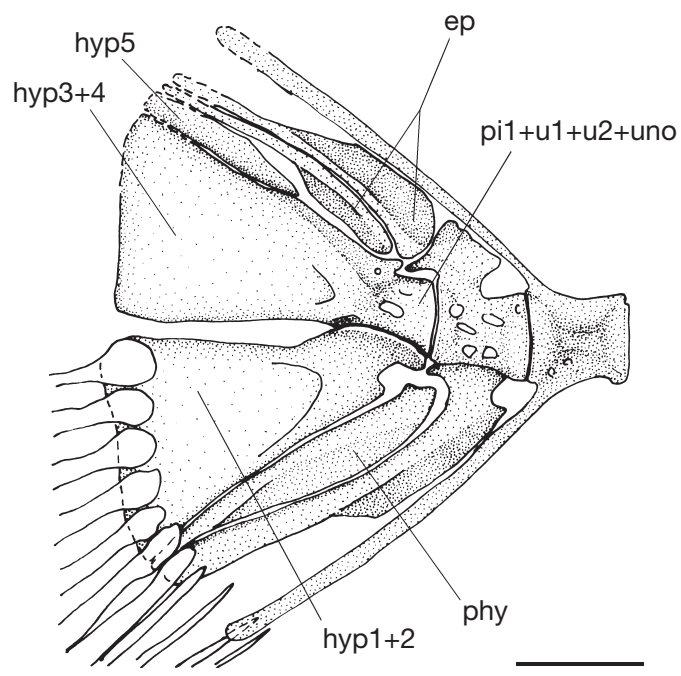

FIG. 4. - Bellwoodilabrus landinii n. gen., n. sp., reconstruction of the caudal skeleton, right side, lateral view. Abbreviations: ep, epural; hyp, hypural; phy, parhypural; pi, preural centrum; u, ural centrum; uno, uroneural. Scale bar: $1 \mathrm{~mm}$.

to the substratum in the deep and clam settings surrounding central Tethyan hard grounds or coral reefs, which were present in the vicinity of the "Pesciara di Bolca" depositional environment (see Bellwood 1996; Landini \& Sorbini 1996).

\section{THE EARLY EVOLUTIONARY HISTORY}

\section{OF LABRID FISHES}

Fishes of the family Labridae are widespread members of the shallow marine tropical and subtropical regions around the world, with a center of diversity on coral reefs in the Western Pacific and Indian Ocean (e.g., Bellwood \& Hughes 2001). These fishes have invaded temperate waters several times during their evolutionary history; Westneat \& Alfaro (2005) documented at least four origins of taxa that inhabit cold northern or southern Pacific waters and at least three clades with temperate eastern Pacific members. As discussed above, labrids are among the most morphologically and ecologically diversified families of marine fishes (see Westneat et al. 2005). For this reason, the evolutionary and biogeographic history of the family Labridae are extremely complex and difficult to define. In addition, labrids are poorly represented in the fossil 
record, and most of the referred material consists of isolated teeth or pharyngeal bones (e.g., Landini 1976; Long 1992; Schultz \& Bellwood 2004), which are scarcely informative about their generic or suprageneric affinities. Fossils often constitute a minimal record of the age of a taxon, but do provide good minimum estimates of the timing of lineage divergence events (Benton \& Ayala 2003; Reisz \& Müller 2004). Molecular phylogenetics resolved the relationships existing within the Labridae, providing a well-supported hypothesis of subfamilial interrelationships. In such a context, the fossil record, even if meager, could be useful in defining some aspects of the evolutionary history of this family.

The origin of the family Labridae cannot be confidently interpreted because of the uncertain position of this family within the Perciformes and the elusiveness of an higher-level phylogeny of labroid fishes. Therefore, the inadequate definition of perciform intrarelationships and the incompleteness of the fossil record make it extremely problematic to evaluate the timing of the labrid origination event. The oldest records of the Labridae are from the Eocene of Monte Bolca (Patterson 1993). The Monte Bolca fish fauna includes the first representatives of many families found on coral reefs today (Bellwood 1996). Bellwoodilabrus landinii n. gen., n. sp. brings the number of labrid taxa known from Monte Bolca to three (see Bellwood 1999). Like Bellwoodilabrus landinii n. gen., n. sp., the other two labrid taxa, Eocoris bloti Bannikov \& Sorbini, 1990 and Phyllopharyngodon longipinnis Bellwood, 1990, are solely represented by the holotype (Bannikov \& Sorbini 1990; Bellwood 1990). The extreme rarity of these fishes among the extraordinarily abundant material collected from this locality probably reflects their low abundance in the original depositional environment. Phyllopharyngodon longipinnis was interpreted as a member of the Hypsigenyini based on the phyllodont tooth development in the pharyngeal jaws, representing one of the earliest representatives of this group (Bellwood 1990). The affinities of Eocoris bloti were not discussed in detail and Bannikov \& Sorbini (1990) considered it as one of the most primitive labrids known. However, Eocoris Bannikov \& Sorbini, 1990 shares many features with pseudocheiline taxa (serrated preopercle; 5(?) branchiostegal rays; 25 vertebrae; first neural spine not shortened; fifth hypural extremely reduced; anal-fin formula III+9; 15 pectoral rays; see Westneat 1993) to which it can be tentatively referred. Therefore, considering the whole labrid diversity represented within the Monte Bolca fish fauna, at least three lineages (hypsigenyines; pseudocheilines; Bellwoodilabrus $\mathrm{n}$. gen.) were already present during the upper part of the Ypresian. According to the phylogenetic analysis proposed by Westneat \& Alfaro (2005), the Hypsigenyini is basal to all the other groups of the family, and includes the odacines. Moreover, a clade formed by labrines + scarines + cheilines is the sister group of the pseudocheilines, novaculines and julidines (including pseudolabrines and labrichthyines). If the pseudocheiline affinities of Eocoris will be confirmed, the Eocene occurrence of this group necessarily implies that the clade formed by labrines, scarines and cheilines was already in existence in the early Eocene. The oldest representatives of both labrines and scarines date back to the Middle Miocene (Badenian) of Austria (Bellwood \& Schultz 1991; Schmid et al. 2001), and a dubious record of the cheilines was reported from the Oligocene of Iran (Arambourg 1967). The possibility of an Eocene origin of the scarines, however, is consistent with molecular clock estimates, which suggest that the date of origin of this group is more than $40 \mathrm{Ma}$ (Streelman et al. 2002). As a final note, as far as the origin of novaculines and julidines is concerned, the fossil record appears to be scarcely informative, but recent molecular studies suggested a Miocene origin for some extant genera (Barber \& Bellwood 2005; Read et al. 2006).

\section{Acknowledgements}

We wish to thank Walter Landini (Dipartimento di Scienze della Terra, Università di Pisa, Pisa), David R. Bellwood (Department of Marine Biology, James Cook University, Townsville), Dr Martin F. Gomon (Ichthyology, Sciences Department, Museum Victoria, Melbourne), and Dr Barry Russell 
(Department of Natural Resources, Environment and the Arts, Arafura Timor Research Facilities, Darwin) for their suggestions and critical review of an early draft of the text. We are very grateful to Dr Alessandra Aspes, Director of the MCSNV, for providing funding for travel of AFB in January 2008 to Verona. Drs Roberto Zorzin and Anna Vaccari (MCSNV) provided the equipment, facilities and place for this project, and Mrs Bruna Burato (MCSNV) helped us with the old literature. $\mathrm{Mr}$ Francesco Sorbini made the photographs for Figure 1. For reviewing the manuscript and providing many constructive suggestions for its improvement we are particularly grateful to Olga Otero (iPHEP, Université de Poitiers, Poitiers) and an anonymous reviewer. Thanks are also due to Federica Giudice for the improvement of the English. The research of AFB was supported by RFBR, gran no. 09-0500170. The names of the authors are in alphabetical order since each made a substantial contribution to this manuscript.

\section{REFERENCES}

AleXANDer R. MCNeILl. 1989. - Dynamics of Dinosaurs and Other Extinct Giants. Columbia University Press, New York, 167 p.

Alfaro M. E., Bolnick D. I. \& Wainwright P. C. 2005. - Evolutionary consequences of many-to-one mapping of jaw morphology to mechanics in labrid fishes. The American Naturalist 165: 140-154.

Arambourg C. 1967. - Résultats scientifiques de la Mission C. Arambourg en Syrie et en Iran (19381939). II. Les poissons oligocènes de l'Iran. Notes et Mémoires sur le Moyen-Orient 8: 1-210.

Bannikov A. F. \& Carnevale G. 2007. - The Eocene "Dules" temnopterus Agassiz, 1836 from Monte Bolca, and the problem of classifying fossil percoid fishes. Palaeontographia Italica 91: 69-84.

BANNIKOV A. F. \& SORBINI L. 1990. - Eocoris bloti, a new genus and species of labrid fish (Perciformes, Labroidei) from the Eocene of Monte Bolca, Italy. Studi e Ricerche sui Giacimenti Terziari di Bolca 6: 133-148.

Barber P. H. \& Bellwood D. R. 2005. - Biodiversity hotspots: evolutionary origins of biodiversity in wrasses (Halichoeres: Labridae) in the Indo-Pacific and new world tropics. Molecular Phylogenetics and Evolution 35: 235-253.

BAREL C. D. N. 1983. - Towards a constructional morphology of cichlid fishes (Teleostei, Perciformes). Netherlands Journal of Zoology 33: 357-424.

Bellwood D. R. 1990. - A new fossil fish Phyllopharyngodon longipinnis gen. et sp. nov. (family Labridae) from the Eocene, Monte Bolca, Italy. Studi e Ricerche sui Giacimenti Terziari di Bolca 6: 149-160.

BellwoOd D. R. 1994. - A phylogenetic study of the parrotfishes family Scaridae (Pisces: Labroidei), with a revision of genera. Records of the Australian Museum Supplement 20: 1-86.

BELLWOOD D. R. 1996. - The Eocene fishes of Monte Bolca: the earliest coral reef fish assemblage. Coral Reefs 15: 11-19.

BELLWOOD D. R. 1999. - Fossil pharyngognath fishes from Monte Bolca, Italy, with a description of a new pomacentrid genus and species. Studi e Ricerche sui Giacimenti Terziari di Bolca 8: 207-217.

Bellwood D. R. \& Schultz O. 1991. - A review of the fossil record of the parrotfishes (Labroidei: Scaridae) with a description of a new Calotomus species from the Middle Miocene of Austria. Annalen des Naturhistorisches Museum Wien 92A: 55-71.

Bellwood D. R. \& Hughes T. P. 2001. - Regionalscale assembly rules and biodiversity of coral reefs. Science 292: 1532-1534.

Bellwood D. R. \& Wainwright P. C. 2001. — Locomotion in labrid fishes: implications for habitat use and cross-shelf biogeography on the Great Barrier Reef. Coral Reefs 20: 139-150.

Bellwood D. R., Wainwright P. C., Fulton C. J. \& Hoey A. S. 2006. - Functional versatility supports coral reef biodiversity. Proceedings of the Royal Society B 273: 101-107.

Benton M. J. \& Ayala F. J. 2003. - Dating the tree of life. Science 300: 1698-1700.

Bleeker P. 1862. - Conspectus generum Labroideorum analyticus. Verslagen Akademie Amsterdam 13: 94-109.

Bцот J. 1969. — Les poissons fossiles du Monte Bolca classés jusqu'ici dans les familles des Carangidae, Menidae, Ephippidae, Scatophagidae. Studi e Ricerche sui Giacimenti Terziari di Bolca 1: 1-525.

Clements K. D., Alfaro M. E., Fessler J. L. \& WestNEAT M. W. 2004. - Relationships of the temperate Australasian labrid fish tribe Odacini (Perciformes; Teleostei). Molecular Phylogenetics and Evolution 32: 575-587.

Collar D. C., Wainwright P. C. \& Alfaro M. E. 2008. - Integrated diversification of locomotion and feeding in labrid fishes. Biology Letters 4: 84-86.

Dullemeijer P. 1974. - Concepts and Approaches in Animal Morphology. Van Gorcum, Assen, 264 p.

Ferry-Graham L. A., Wainwright P. C., Westneat M. W. \& BellWoOd D. R. 2002. - Mechanics of benthic prey capture in wrasses (Labridae). Marine Biology 141: 819-830. 
Fujita K. 1990. - The Caudal Skeleton of Teleostean Fishes. Tokai University Press, Tokyo, 897 p.

Fulton C. J., Bellwood D. R. \& Wainwright P. C. 2001. - The relationship between swimming ability and habitat use in wrasses (Labridae). Marine Biology 139: 25-33.

GaUdANT J. 1997. — Les poissons pétrifiés du Monte Bolca (Italie) et leur influence sur les théories de la Terre au milieu du siècle des Lumières, d'après un manuscrit inachevé de Jean-François Seguier (17031784). Bulletin de la Société géologique de France 168: 675-683.

GILL T. N. 1893. - Families and subfamilies of fishes. Memoirs of the National Academy of Sciences 6: 91124.

Gomon M. F. 1979. - A revision of the labrid genus Bodianus, with an analysis of the relationships of other member of the tribe Hypsigenyini. Ph.D. Thesis, University of Miami, Miami, USA, 679 p.

Gomon M. F. 1997. - Relationships of fishes of the labrid tribe Hypsigenyini. Bulletin of Marine Science 60: 789-871.

Gould S. J. 1970. - Evolutionary paleontology and the science of form. Earth-Science Reviews 6: 77-119.

GreENwood P. H. 1976. - A review of the family Centropomidae (Pisces, Perciformes). Bulletin of the British Museum (Natural History), Zoology 29: 1-81.

GÜNTHER A. 1861. - A preliminary synopsis of the labroid genera. Annals and Magazine of Natural History 3 (8): 382-389.

Hanel R., Westneat M. W. \& Sturmbauer C. 2002. Phylogenetic relationships, evolution of broodcare behaviour, and geographic speciation in the wrasse tribe Labrini. Journal of Molecular Evolution 55: 776-789.

Hulsey C. D. \& Wainwright P. C. 2002. — Projecting mechanics into morphospace: disparity in the feeding system of labrid fishes. Proceedings of the Royal Society B 269: 317-326.

JoHNSON G. D. 1993. — Percomorph phylogeny: progress and problems. Bulletin of Marine Science 52: 3-28.

Johnson G. D. \& Patterson C. 1993. - Percomorph phylogeny: a survey of acanthomorphs and a new proposal. Bulletin of Marine Science 52: 554-626.

JORDAN D. S. 1923. - A classification of fishes including family and genera as far as known. Stanford Publications in Biological Science 3: 77-243.

JORDAN D. S. \& SNYDER J. O. 1902. - A review of the labroid fishes and related forms found in the waters of Japan. Proceedings of the United States National Museum 24: 595-710.

KaufMan L. \& Liem K. F. 1982. - Fishes of the suborder Labroidei (Pisces: Perciformes): phylogeny, ecology, and evolutionary significance. Breviora 472: 1-19.

LANDINI W. 1976. - Osservazioni sulle placche faringee di alcuni labridi del Pliocene della Toscana. Atti della Società Toscana di Scienze Naturali, Serie A 83: 230-250.

LANDINI W. \& SORBINI L. 1996. - Ecological and trophic relationships of Eocene Monte Bolca (Pesciara) fish fauna, in CHERCHI A. (ed.), Autoecology of selected fossil organisms: achievements and problems. Bollettino della Società Paleontologica Italiana Spec. Vol. 3: 105-112.

LAUDER G. V. 1995. - On the inference of function from structure, in THOMASON J. J. (ed.), Functional Morphology in Vertebrate Paleontology. Cambridge University Press, Cambridge: 1-18.

Liem K. F. \& Greenwood P. H. 1981. — A functional approach to the phylogeny of pharyngognath teleosts. American Zoologist 21: 83-101.

LONG D. J. 1992. - An Eocene Wrasse (Perciformes; Labridae) from Seymour Island. Antarctic Science 4: 235-237.

Monod T. 1968. — Le complexe urophore des poissons téléostéens. Mémoires de l'Institut fondamental d'Afrique Noire 81: 1-705.

NeLSON G. J. 1967. — Gill arches of some teleostean fishes of the families Girellidae, Pomacentridae, Embiotocidae, Labridae and Scaridae. Journal of Natural History 1: 289-293.

Norman J. R. 1966. - A Draft Synopsis of the Orders, Families and Genera of Recent Fishes and Fish-like Vertebrates. British Museum (Natural History), London, $649 \mathrm{p}$.

OTTEN E. 1983. - The jaw mechanism during growth of a generalized Haplochromis species: H. elegans Trewavas, 1933 (Pisces, Cichlidae). Netherlands Journal of Zoology 33: 55-98.

Papazzoni C. A. \& Trevisani E. 2006. - Facies analysis, palaeoenvironmental reconstruction, and biostratigraphy of the "Pesciara di Bolca" (Verona, northern Italy): An early Eocene Fossil-Lagerstätte. Palaeogeography, Palaeoclimatology, Palaeoecology 242: 21-35.

Parenti P. \& Randall J. E. 2000. - An annotated checklist of the species of the labroid fish families Labridae and Scaridae. Ichthyological Bulletin of the J. L. B. Smith Institute of Ichthyology 68: 1-97.

Patterson C. 1993. - Osteichthyes: Teleostei, in Benton M. J. (ed.), The Fossil Record 2. Chapman \& Hall, London: 621-656.

Patterson C. \& Rosen D. E. 1977. - Review of ichthyodectiform and other Mesozoic teleost fishes and the theory and practice of classifying fossils. Bulletin of the American Museum of Natural History 158: 81-172.

RANDALL J. E. 1967. - Food habits of reef fishes of the West Indies. Studies in Tropical Oceanography 5: 655-847.

Rayner J. M. V. \& Wotton R. J. 1991. - Biomechanics in Evolution. Cambridge University Press, Cambridge, $287 \mathrm{p}$. 
Read C. I., Bellwood D. R. \& Van Herwerden L. 2006. - Ancient origins of Indo-Pacific coral reef fish biodiversity: a case study of the leopard wrasses (Labridae: Macropharyngodon). Molecular Phylogenetics and Evolution 38: 808-819.

REGAN C. T. 1913. - The classification of percoid fishes. Annals and Magazine of Natural History 8 (12): 111-145.

ReISZ R. R. \& MÜLLER J. 2004. - Molecular timescales and the fossil record: a paleontological perspective. Trends in Genetics 20: 237-241.

Rognes K. 1973. - Head skeleton and jaw mechanism in Labrinae (Teleostei: Labrinae) from Norwegian waters. Arbok for Universitetet i Bergen. MatematiskNaturvitenskapelig, serie 1971 4: 1-149.

Rosen D. E. \& Patterson C. 1990. - On Müller's and Cuvier's concept of pharyngognath and labyrinth fishes and the classification of percomorph fishes, with an atlas of percomorph dorsal gill arches. American Museum Novitates 2983: 1-57.

Russell B. C. 1988. - Revision of the fish genus Pseudolabrus and allied genera. Records of the Australian Museum Supplement 9: 1-72.

Schmid H. P., Harzhauser M., Kroh A., Coric S., RöGl F. \& SCHUlTz O. 2001. - Hypoxic events on a Middle Miocene carbonate platform of the Central Paratethys. Annalen des Naturhistorisches Museum Wien 102A: 1-50.

Schultz O. \& Bellwood D. R. 2004. - Trigonodon oweni and Asima jugleri are different parts of the same species Trigonodon jugleri, a Chiseltooth Wrasse from the Lower and Middle Miocene of Central Europe (Osteichthyes, Labridae, Trigonodontinae). Annalen des Naturhistorisches Museum Wien 105A: 287-305.

SPRINGER V. G. \& Johnson G. D. 2004. - Study of the dorsal gill-arch musculature of teleostome fishes, with special reference to the Actinopterygii. Bulletin of the Biological Society of Washington 11: 1-235.

StiASSNY M. L. J. \& JenSEN J. S. 1987. — Labroid intrarelationships revisited: morphological complexity, key innovations, and the study of comparative diversity. Bulletin of the Museum of Comparative Zoology 151: 269-319.

Streelman J. T., Alfaro M., Westneat M. W., Bellwood D. R. \& KARL S. A. 2002. - Evolutionary history of the parrotfishes: biogeography, ecomorphology, and comparative diversity. Evolution 56: 961-971.

Streelman J. T. \& Karl S. A. 1997. - Reconstructing labroid evolution with single-copy nuclear DNA. Proceedings of the Royal Society of London B 264: 1011-1020.

Thorsen D. H. \& Westneat M. W. 2005. - Diversity of pectoral fin structure and function in fishes with labriform propulsion. Journal of Morphology 263: 133-150.

Van Hasselt M. J. F. M. 1978. — A kinematic model for the jaw movements in some Labrinae (Pisces, Perciformes). Netherlands Journal of Zoology 28: 545558.

Van Hasselt M. J. F. M. 1979. - Morphology and movements of the jaw apparatus in some Labrinae. Netherlands Journal of Zoology 29: 52-108.

WainWRight P. C. 1987. - Biomechanical limits to ecological performance: mollusc crushing by the Caribbean Hogfish, Lachnolaimus maximus (Labridae). Journal of Zoology, London 213: 283-297.

WAINWRIGHT P. C. 1988. - Morphology and ecology: the functional basis of feeding constraints in Caribbean labrid fishes. Ecology 69: 635-645.

Wainwright P. C., Bellwood D. R. \& Westneat M. W. 2002. - Ecomorphology of locomotion in labrid fishes. Environmental Biology of Fishes 65: 47-62.

Wainwright P. C., Bellwood D. R., Westneat M. W., Grubich J. R. \& Hoey A. S. 2004. - A functional morphospace for the skull of labrid fishes: patterns of diversity in a complex biomechanical system. Biological Journal of the Linnean Society 82: 1-25.

Walker J. A. \& Westneat M. W. 2000. — Mechanical performance of aquatic rowing and flying. Proceedings of the Royal Society of London B 267: 1875-1881.

Walker J. A. \& Westneat M. W. 2002. - Pectoral fin design and swimming performance in labriform propulsion: a comparison between rowers and flappers. Journal of Experimental Biology 205: 177-187.

WARNER R. R. \& RoBERTSON D. R. 1978. - Sexual patterns of the labroid fishes of the Western Caribbean, I: the wrasses (Labridae). Smithsonian Contribubtions to Zoology 254: 1-27.

Wевв P. W. 1994. - The biology of fish swimming, in Haddock L., Bone Q. \& Rayner J. M. V. (eds), Mechanics and Physiology of Animal Swimming. Cambridge University Press, Cambridge, 45-62.

WeSTNEAT M. W. 1990. — Feeding mechanics of teleost fishes (Labridae): a test of four-bar linkage models. Journal of Morphology 205: 269-295.

Westneat M. W. 1993. - Phylogenetic relationships of the tribe Cheilinini (Labridae: Perciformes). Bulletin of Marine Science 52: 351-394.

WeSTNEAT M. W. 1994. - Transmission of force and velocity in the feeding mechanism of labrid fishes (Teleostei, Perciformes). Zoomorphology 114: 103-118.

Westneat M. W. 1995. — Feeding, function and phylogeny: analysis of historical biomechanics in labrid fishes using comparative methods. Systematic Biology 44: 361-383.

WeSTNEAT M. W. 1996. — Functional morphology of aquatic flight in fishes: kinematics, electromyography, and mechanical modeling of labriform locomotion. American Zoologist 36: 582-592.

Westneat M. W. \& Alfaro M. E. 2005. — Phylogenetic relationships and evolutionary history of the reef fish family Labridae. Molecular Phylogenetics and 
Evolution 36: 370-390.

Westneat M. W., Alfaro M. E., Wainwright P. C., Bellwood D. R., Grubich J. R., Fessler J. L., CleMENTS K. D. \& SMITH L. L. 2005. - Local phylogenetic divergence and global evolutionary convergence of skull function in reef fishes of the family Labridae. Proceedings of the Royal Society B 272: 993-1000.
Westneat M. W. \& Wainwright P. C. 1989. — Feeding mechanism of Epibulus insidiator: evolution of a novel functional system. Journal of Morphology 202: 129-150.

YAMAOKA K. 1978. - Pharyngeal jaw structure in labrid fish. Publications of the Seto Marine Biological Laboratory 24: 409-426.

Submitted on 16 September 2008; accepted on 22 April 2009. 